\title{
DISCRIMINATION AND THE NLRB: THE SCOPE OF BOARD POWER UNDER SECTIONS 8(a)(3) AND 8(b)(2)
}

The scope of sections $8(a)(3)^{1}$ and $8(b)(2)^{2}$ of the National Labor Relations Act has been the subject of renewed attention in recent years. With section $8(b)(1)(A)^{3}$ and $8(b)(3),{ }^{4}$ these sections have been seen as a means of expanding the power of the National Labor Relations Board to deal with racial discrimination and other arbitrary or invidious discrimination against employees. ${ }^{5}$ The NLRB sought to extend its unfair labor practice machinery to cover arbitrary non-racial treatment in Miranda Fuel Co., ${ }^{6}$ and racial discrimination in Independent Metal Workers, Local 1 \& 2.7 The implications of such an expansion of Board

149 Stat. 452 (1935), as amended, 29 U.S.C. $\$ 158(a)(3)$ (1958).

261 Stat. 140 (1947), 29 U.S.C. § 158(b)(2) (1958).

361 Stat. 140 (1947), 29 U.S.C. $\S 158(\mathrm{~b})(\mathrm{I})(\mathrm{A})$ : "It shall be an unfair labor practice for a labor organization or its agents-(1) to restrain or coerce (A) employees in the exercise of the rights guaranteed in section [7]: Provided, That this paragraph shall not impair the right of a labor organization to prescribe its own rules with respect to the acquisition or retention of membership therein; ..."

461 Stat. 140 (1947), 29 U.S.C. $\S 158(b)(3)$ (1958): "It shall be an unfair labor practice for a labor union or its agents-(3) to refuse to bargain collectively with an employer, provided it is the representative of his employees ...."

5 See generally Sovern, Racial Discrimination and the National Labor Relations Act: The Brave New World of Miranda, New York UNrversity SIXTEentr ANNuAL CoNFERENCE ON LABOR 3 (1963); Cox, The Duty of Fair Representation, 2 VILL. L. REV. 151 (1957); Sovern, The National Labor Relations Act and Racial Discrimination, 62 Colum. L. Rev. 563 (1962); Comment, 112 U. PA. L. REv. 711 (1964); Note, 42 TExAS L. Rev. 917 (1964).

6140 N.L.R.B. 181 (1962), enforcement denied, 326 F.2d 172 (2d Cir. 1963). But cf. Stout v. Construction \& General Laborers Dist. Council, 226 F. Supp. 673 (N.D. Ill. 1963).

7147 N.L.R.B. No. 166 (1964). The union maintained two locals at the Hughes Tool Company in Houston, Texas, one representing white employees of the company and the other representing Negro employees. The locals were jointly certified in 1959 as bargaining representatives of the company's employees. After the two locals were unable to agree in 1961 on a proposal for eliminating racial segregation, the Negro local refused to sign a new contract. The company and white local signed the contract and put it into effect. When the white local and the company later agreed to increase the number of apprenticeships, which under the new contract were available only to white employees, a Negro employee bid for one of the apprenticeships. After his bid was rejected, he asked the white local to represent him in processing a grievance protesting the matter but received no reply from the president of the local. The employee filed an unfair labor practice charge alleging that the local's refusal to process his grievance was unlawful restraint and coercion under section $8(\mathrm{~b})(1)(\mathrm{A})$. A 
power are far reaching. The NLRB, already heavily burdened, may be inundated with allegations of various types of discrimination by any employee who feels mistreated by his employer or union. If such alleged injustices are arguably unfair labor practices, the Board's primary jurisdiction may preempt other tribunals. The jurisdiction of other administrative agencies, such as state fair employment practices commissions, would thus be doubtful. ${ }^{8}$ Also, a policy conflict with the Equal Employment Opportunity Law, Title VII of the Civil Rights Act of 1964,9 is possible. Finally, if the Board's power is extended to adjudicate charges of racial discrimination, the Board must consider practices and policy objectives which are beyond its labor relations expertise and which have been committed, in large part, to other tribunals.

Although the matter bristles with doubt, the courts may approve such expansion of Board power in construing sections $8(\mathrm{~b})(1)(\mathrm{A}), 8(\mathrm{~b})(2)$ and $8(a)(3)$, or $8(b)(3)$. The latter section seems to deal with formal bargaining and grievance prosecution, but it has been said to be violated by a union which practices any invidious discrimination toward its members. ${ }^{10}$ Greater support has been generated for reliance by the Board on section $8(\mathrm{~b})(1)(\mathrm{A})$, in dealing with such discrimination. ${ }^{11}$ The sub-

complaint was issued. The Negro local later asked rescission of the joint certification, contending that the segregated locals and the practices of the white local in discriminating against Negroes invalidated the certification.

All five members of the Board agreed that the union's certification should be rescinded. All five also agreed that the refusal to process the grievance was illegal coercion of an employee and violated $8(\mathrm{~b})(\mathrm{I})(\mathrm{A})$. A three member majority went further and held that the refusal to process the grievance was a refusal to bargain collectively with the company, hence a violation of section $8(\mathrm{~b})(3)$, and caused the company to discriminate against the employee, a violation of section $8(\mathrm{~b})(2)$.

Two members dissented from the 8(b)(2) and (3) holdings. They contended that there was a procedural bar to considering the issue since the formal complaint had charged only an $8(\mathrm{~b})(1)$ (A) violation. Secondly, they disagreed with the holding that a union violates $8(\mathrm{~b})(2)$ when it causes discrimination based on race. They contended that section 8(b)(2) proscribes only discrimination related to "union membership, loyalty, the acknowledgement of union authority, or the performance of union obligations."

See also Local 1867, Int'l Longshoremen's Ass'n, 148 N.L.R.B. No. 44 (1964). In this case the union maintained and enforced a $75-25 \%$ work distribution between the Negro and white locals involved in collective bargaining agreements with employer associations, and enforced a "no doubling" arrangement forbidding white and Negro gangs being assigned to work together in ship hatches. The Board affirmed the examiner's findings of an $8(\mathrm{~b})(\mathrm{I})(\mathrm{A})$ violation. The Board also affirmed a finding of violation of section 8(b)(2) and an employer violation of section 8(a)(3). A majority of the Board further found an $8(b)(3)$ violation, two members of the Board dissenting in agreement with the trial examiner's refusal to find such a violation.

8 See text accompanying notes $90-92$ infra.

978 Stat. 241 (1964).

10 Local 1367, Int'I Longshoremen's Ass'n, 148 N.L.R.B. No. 44 (1964); Independent Metal Workers, Local 1 \&\& 2, supra note 7; Miranda Fuel Co., supra note 6. See generally Cox, The Duty of Fair Representation, 2 VILL. L. REy. 151 (1957).

11 See note 5 supra. 
stantive question whether section $8(\mathrm{~b})(\mathrm{I})(\mathrm{A})$ is so broad has been extensively treated elsewhere. ${ }^{12}$ This comment will not treat that section or 8(b)(3), but will concentrate on interpretation of sections 8(a)(3) and $8(b)(2)$. It should be noted, however, that unfair labor practices under these various sections provide cumulative remedies; consequently, even though a particular section might be inappropriate the same activity could be reached through another. It should also be noted that many of the policy arguments, discussed later, against the expansion of Board power apply with equal force to unfair labor practices under any of these sections.

In considering the scope of sections $8(a)(3)$ and $8(b)(2)$ this comment will examine Supreme Court decisions which lead to the conclusion that the scope of the sections depends critically upon the definition of discrimination, since the other elements of a violation may be found readily as derivatives of the discriminatory conduct. Despite its importance, the definition of discrimination is far from clear, even at this late date, as illustrated by the recent NLRB decisions contrasted with two recent cases in the Second Circuit, ${ }^{13}$ the only two court cases this writer has discovered which wrestle with the problem. This comment will examine the respective positions of the Board and the Second Circuit in the light of the Supreme Court cases, the legislative history, and the implications of expanded Board power. It will be urged that a restrictive reading be given to the statute by limiting the discrimination covered by sections $8(a)(3)$ and $8(b)(2)$ to that based on union relationships or activities.

Section 8(a)(3) of the National Labor Relations Act provides that it shall be an unfair labor practice for an employer

by discrimination in regard to hire or tenure of employment or any term or condition of employment to encourage or discourage membership in any labor organization ....14

Section $8(b)(2)$ in turn makes it an unfair labor practice for a labor organization or its agents "to cause or attempt to cause an employer to discriminate against an employee in violation of [Section 8(a)(3)]. . ."15

"Discrimination," as used in section $8(a)(3)$, might reasonably have three meanings:

(1) any differentiation or distinction;

\section{Ibid.}

13 NLRB v. Miranda Fuel Co., 326 F.2d 172 (2d Cir. 1963); NLRB v. Local 294, Int'l Bhd. of Teamsters, 317 F.2d 746 (2d Cir. 1963).

1449 Stat. 452 (1935), as amended, 29 U.S.C. § 158(a)(3) (1958).

1561 Stat. 140 (1947), 29 U.S.C. § 158(b)(2) (1958). 
(2) any invidious distinction or differentiation based upon or motivated by union relationships;

(3) differentiation or distinction without sufficient reason, a meaning commonly conveyed by use of the adjectives "arbitrary" or "invidious."

In addition to discrimination, the courts have often spoken of motive or purpose as an element of violation of the statute; and section 8(a)(3) indicates that the effect of encouragement or discouragement is another requisite. It will be seen, however, that under the Supreme Court's present construction the elements of purpose or motive and of effect are not limiting factors, and consequently the scope of the statute depends entirely upon the definition of discrimination adopted.

The Supreme Court has frequently stated that the employer's intent to encourage or discourage union membership is an element of an $8(a)(3)$ violation. ${ }^{16}$ However, the requirement has been discarded as an independent element because of the ease with which intent may be inferred from the probable consequences of employer action. Radio Officers Union $v . N L R B^{17}$ is illustrative. The three cases in Radio

16 See, e.g., Local 357, Int'l Bhd. of Teamsters v. NLRB, 365 U.S. 667 (1961); Radio Officers Union v. NLRB, 347 U.S. 17 (1954); Phelps Dodge Corp, v. NLRB, 313 U.S. 177 (1941); NLRB v. Jones \& Laughlin Steel Corp., 301 U.S. 1 (1937).

17347 U.S. 17 (1954). Three cases alleging discrimination by the employer at the request of a union were consolidated in Radio Officers. In NLRB v. Local 41, Int'l Bhd. of Teamsters, the Board had issued an order against the union finding violation of sections $8(\mathrm{~b})(\mathrm{I})(\mathrm{A})$ and $8(\mathrm{~b})(2)$. The Board found that the union, which periodically furnished a seniority list to the company, dropped a driver to the bottom of the list for not paying his dues on time. As a result the driver was denied driving assignments he would otherwise have obtained and for which he would have been paid. The Eighth Circuit denied the Board's petition to enforce its order, holding that there was abundant support for the conclusion that the employer was caused to discriminate against the driver, but no evidence to support a conclusion that employees were or would be encouraged or discouraged.

In Radio Officers Union v. NLRB, the Board had found violations of $8(\mathrm{~b})(\mathrm{I})(\mathrm{A})$ and 8(b)(2) where the union had caused the employer to replace a radio operator, a union member, because he had not been referred by the union but had been called directly by the employer. The Board found that the contract did not provide for a hiring hall arrangement, which would have legalized the actions in the case, but rather gave the employer the right of free selection so long as the men called were union members in good standing. The Board found that the union, by causing the operator's discharge for not following the union's hiring hall rules, was not acting in conformity with a contract and therefore restrained the employee in his right to refrain from observance of the union's rules, and caused the company to discriminate against him by denying him employment. 347 U.S. at 31. The Second Circuit granted enforcement of the Board's order.

In NLRB v. Gaynor News Co. the Second Circuit granted enforcement of the Board's order finding 8(a)(1), (2) and (3) violations where the employer gave retroactive wage increases and vacation payments to employees who were union members and refused such benefits to other employees. Though nonmembers had been denied admission to the union because of a primogeniture requirement, the Board concluded that the 
Officers were the first cases involving the problem of encouragement of union membership to reach the Court. ${ }^{18}$ In considering whether "proof of motive" is required to find a violation, the Court said, "that Congress intended the employer's purpose in discriminating to be controlling is clear."19 It added, however, that

it is also clear that specific evidence of intent to encourage or discourage is not an indispensable element of proof of violation of $\S 8(\mathrm{a})(3) \ldots[\mathrm{P}]$ roof of certain types of discrimination satisfies the intent requirement. This recognition that specific proof of intent is unnecessary where employer conduct inherently encourages or discourages union membership is but an application of the common law rule that a man is held to intend the forseeable consequences of his conduct. 20

On a later occasion the Court reiterated:

It is the "true purpose" or "real motive" in hiring or firing that constitutes the test. . . . Some conduct may by its very nature contain the implications of the required intent; the natural forseeable consequences of certain action may warrant the inference. ${ }^{21}$

Motive and intent have distinct meanings in the law; motive being the underlying cause or reason moving one to the action, intent the purpose to use a particular means to effect the result. In discussing unfair labor practices, the Supreme Court has blurred this distinction, thereby hindering careful analysis of the statute. For instance, in one recent case the Court said,

Cases in this Court dealing with unfair labor practices have recognized the relevance and importance of showing the employer's intent or motive to discriminate or to interfere with union rights. But specific evidence of such subjective intent is "not an indispensable element of proof of violation." 22

discrimination "had the natural and probable effect not only of encouraging non-union employees to join the union, but also of encouraging union employees to retain their union membership." 347 U.S. at 37. See generally The Supreme Court, 1953 Term, 68 Harv. L. Rev. 145 (1954); Recent Cases, 42 Geo. L.J. 542 (1954); 7 VAND. L. Rev. 722 (1954).

18 Radio Officers Union v. NLRB, 347 U.S. 17, 39 (1954). Since in two of the cases the discrimination was directed at union members, the Court first dealt with the meaning of "membership in any labor organization." The Court interpreted encouraging membership to include encouraging to "stay in good standing" in the union.

19 Id. at 44.

$20 \mathrm{Id}$. at 45.

21 Local 357, Int'l Bhd. of Teamsters v. NLRB, 365 U.S. 667, 675 (1961).

22 NLRB v. Erie Resistor Corp., 373 U.S. 221, 227 (1963). See also cases cited note 16 supra. 
Thus, the Court has been careful not to disavow its early language about an intent or motive requirement although the requirement is considerably diluted.

It is clear from the statute itself that the Court need not persist in stating there is such a requirement. Clearly, purpose to encourage or discourage would be an element of a violation if section 8(a)(3) read "by discrimination ... in order to encourage or discourage." Justice Black, dissenting in Radio Officers, called the "in order to" wording "the plain and long accepted meaning of $\S 8(a)(3) " 23$ and contended it should be followed in that case. The original Senate bill in 1934 referred to "any discriminatory practice ... which encourages," 24 a reading which tends toward absolute liability for discriminatory conduct having the requisite effect regardless of a purpose of encouragement or discouragement. That language was changed in committee to the language of the subsequent act, language which may be read either way. ${ }^{25}$ It should also be noted that the House Committee Report on the original Senate bill said "under section 8(3) any discrimination is outlawed which tends to 'encourage or discourage.' . . ."26 Purpose to encourage is not a requirement of the language of $8(a)(3)$. And purpose to discriminate may be found so easily from the discriminatory conduct itself as not to be an element.

If motive, broadly speaking, is that which incites or induces one to action, it is also doubtful, in the light of what concerned Congress in $1947,{ }^{27}$ that motive is necessary to a violation of section 8(a)(3). Certainly in 1935 Congress was concerned about employer discrimination motivated by his desire to encourage participation in certain independent unions or to discourage any unionism..$^{28}$ But in 1947 , when $8(\mathrm{~b})(2)$ was added to the statute, Congress was concerned about union coercion, under union security agreements or otherwise, compelling employers to discharge or take other differential action against particular employees. The employer in such cases acted because of the provisions of a contract, or because of duress; perhaps out of fear of union reprisals or the economic costs of

23 Radio Officers Union v. NLRB, 347 U.S. 17, 57-58 (1954).

241 NLRB, Legislative History of the National Labor Relations Act (1935) 3 (1949) [hereinafter cited as Legrs. HIST. 1935]. (Emphasis added.)

$25 C f$. Judge Friendly dissenting in NLRB v. Miranda Fuel Co., 326 F.2d 172 (2d Cir. 1963), "what Congress forbade was "to encourage or discourage membership in any labor organization' by 'discrimination in regard to hire or tenure of employment.'" Id. at 181. The formulation which would result in absolute liability would say that whenever encouragement or discouragement results from discrimination, there is a violation.

262 LEGIS. HIsr. 1935 at 307l. (Emphasis added.)

27 See text accompanying notes 66-76 infra.

28 See text accompanying notes 58-65 infra. 
incurring a dispute with the union over the treatment of one worker. Congress recognized that the employer was whipsawed. Motivated by other considerations, such as preserving industrial peace, he was coerced by the union into violation of the statute. Only in the most fictional sense was there a motive "to encourage" unionism on the part of the employer.

In short, despite the confusion in language, motive is not required by the statute. Purpose or intent, whether required by the statute or not, is so easily inferred from the probable consequences of conduct as to be irrelevant as an independent factor. The Court's discussion of intent or purpose as a requirement may serve to preserve the appearance of not departing from the requirement first read into the statute in 1937,29 but now, as then, it is neither an obstacle to nor a requisite for finding a violation.

The third factor which is spoken of as an element of a violation-this one apparently required by the statute-is the effect of encouragement or discouragement of union membership. ${ }^{30}$ Although the impact of the employer's differential treatment on employees is thus crucial to establishing a violation, a specific finding of the actual effect on employees is also unnecessary. The three cases in Radio Officers reached the Supreme Court after a conflict in the circuits over whether there must be specific proof that the discrimination did or would encourage or discourage membership in a labor organization. The Court concluded that actual proof of employee response is not required where encouragement or discouragement can be reasonably inferred from the nature of the differential treatment. ${ }^{31}$ The Board is to apply its special competence and expertise in weighing the conduct and the circumstances and draw that inference from the conduct. The inferences about effect are thus dependent upon the nature of the conduct. As will be demonstrated below, ${ }^{32}$ the necessary inferences may easily be drawn in any case.

The resulting interrelationship is readily apparent. Where discriminatory conduct is shown, the probable effects may be inferred, if necessary, from the nature of the conduct. The employer's purpose or intent may also be presumed because of the probable consequences of his conduct. The inquiry into a possible violation is thus focussed on discrim-

29 NLRB v. Jones \& Laughlin Steel Corp., 301 U.S. 1, 47 (1937).

30 The term "membership," as it was defined in Radio Officers Union v. NLRB, 347 U.S. 17, 39-40 (1954), includes "membership in good standing." See also NLRB v. Erie Resistor Corp., 373 U.S. 221 (1963). In discussing both 8(a)(1) and 8(a)(3) violations the Court speaks there of the "interests of employees in concerted activity," $i d$. at 229, and also says "membership in any labor organization" in section 8(a)(3) includes "participation in concerted activities." Id. at 233.

31347 U.S. at 48-52.

32 See text accompanying notes $39-41$ infra. 
inatory conduct, with the other "elements" inferred or presumed therefrom.

The definition of discrimination is thus crucial-absent a showing of specific inten $t^{33}$ to encourage or discourage membership-to a determination of the scope of sections $8(\mathrm{a})(3)$ and $8(\mathrm{~b})(2)$. Since the Board possesses wide latitude to draw inferences and, as will be shown below, the necessary reasonable inferences may easily be drawn when there is any differential treatment by an employer, the scope of sections $8(a)(3)$ and $8(b)(2)$ depends entirely on the definition of discrimination.

Two recent cases decided in the Second Circuit, illustrate the difficulties and consequences of defining discrimination. In NLRB v. Miranda Fuel $C o .^{34}$ the employer acquiesced in the union agent's demand that a truck driver be dropped to the bottom of the seniority list. At first the basis for the union's demand was that the driver had returned late from a summer leave period, thus forfeiting his seniority rights under the contract. When the union found that the tardiness was excused because of illness, it changed its position and rested its demand on the driver's having left three days earlier than the date specified in the contract (leaving on Friday instead of waiting until Monday), though he had done so with the employer's permission.

The NLRB's unfair labor practice order was based in part on a finding of violation of sections $8(\mathrm{a})(3)$ and $8(\mathrm{~b})(2)$ by the employer and union. ${ }^{35}$ The Board held that $8(\mathrm{a})(3)$ and $8(\mathrm{~b})(2)$ are violated when,

for arbitrary or irrelevant reasons or upon the basis of an unfair classification, the union attempts to cause or does cause an employer to derogate the employment status of an employee. ${ }^{36}$

33 Even though it may not be possible to infer the requisite intent, a finding of specific intent will impeach conduct which otherwise appears legitimate. NLRB v. Erie Resistor Corp., 373 U.S. 221, 227-28 (1963).

34140 N.L.R.B. 181 (1962), enforcement denied, 326 F.2d 172 (2d Cir. 1963).

35 In Miranda, the Board also found violations of sections $8(a)(1)$ and $8(b)(1)(A)$. The latter was based on the theory that the union's duty of fair representation created a section 7 right of employees to be represented fairly. The union's arbitrary request singling out one driver to be dropped in seniority for an insufficient reason was held to violate its duty of fair representation; hence it constituted restraint and coercion of the employee's section 7 right. This novel theory was rejected by Judge Medina in his opinion in Miranda. Judge Lumbard thought it unnecessary to reach the question since he felt there was insufficient evidence to support the conclusion that the union took "hostile action for irrelevant, unfair, or invidious reasons" against the employer. Judge Friendly's dissent dealt only with the 8(b)(2)-8(a)(3) question. Regarding the duty of fair representation as an unfair labor practice, see generally Sovern, Racial Discrimination and the National Labor Relations Act: The Brave New World of Miranda, NEW York UNIVERSITY SIXTEenth ANNUAL CoNference oN LABOR 3 (1963); Comment, 112 U. PA. L. REv. 711 (1964); Note, 42 TeXas L. REv. 917 (1964). Cox, The Duty of Fair Representation, 2 VILL. L. REv. 151 (1957); See also Sovern, The National Labor Relations Act and Racial Discrimination, 62 ColUM, L. REv. 563 (1962).

30140 N.L.R.B. at 186. 
Judge Friendly, vigorously dissenting to the Second Circuit's denial of enforcement of the Board's order, ${ }^{37}$ restated the Board theory as follows: under the act discrimination need not be based on union membership or activity-any arbitrary action which had the effect of encouraging union membership was prohibited. The Board could reasonably have concluded that the employer's arbitrary action, taken at the instigation of the union, would tend to encourage membership by demonstrating the union's power and leading employees to conclude they should get closer to or be in good standing with the source of such power.

The Board's theory of encouragement by employer acquiescence in an arbitrary union request, restated by Judge Friendly, is a reasonable one and is suggested by language in Radio Officers. Although the discrimination in that case was based on union considerations, the Court stated, "since encouragement of union membership is obviously a natural and foreseeable consequence of any employer discrimination at the request of a union, those employers must be presumed to have intended such encouragement."'38

As expressed in Radio Officers, "the policy of the Act is to insulate employees' jobs from their organizational rights." 39 Since the TaftHartley amendments, those rights include the right to refrain from participation in union activities. Yet the employee's willingness to exercise his right to be a bad or indifferent union member may be curtailed by a demonstration of the power of a union agent to get the employer to take action affecting jobs. Although the union's request, and the employer's discrimination, may not be related to organizational activities, employees may cooperate more willingly in union matters in order to curry favor with a source of power which may be exercised arbitrarily. If that is indeed the effect, then the employer's differential treatment taken at the union's request is discrimination which encourages union membership.

It should be noted that the Board's logic-that any discriminatory action taken because of union instigation supports an inference of encouragement-can easily be extended so that any differential treatment by an employer, although taken without any hint of union instigation, supports an inference of encouragement. Assume the employer fires a Negro or redhead simply because he does not like Negroes or redheads. In the proper circumstances the Board could conclude that the employer's action, which the union could not prevent, demonstrated the weakness of the union, and thereby discouraged enthusiasm for union membership.

37326 F.2d 172, 180 (2d Cir. 1963).

38347 U.S. at 52. (Emphasis added.)

39347 U.S. at 40 . 
Or the Board could conclude that the employer's action stimulated participation in the union in an effort to make the union's economic position powerful enough to prevent such action in the future. ${ }^{40}$ "The possibility of drawing either of two inconsistent inferences from the evidence [does] not prevent the Board from drawing one of them . . . ."41

Insofar as the Board's theory is concerned, it should be apparent that the Board could reasonably draw an inference that encouragement was a probable consequence of any differential treatment by the employer taken at the union's request. And since the drawing of that inference is a judgment that such an effect was a probable consequence of the employer's conduct, the employer's purpose-if a finding of it is necessarymay also be presumed.

The Board majority in Miranda considered the encouragement theory to be the teaching of Radio Officers. The Board qualified its holding slightly, however, in the light of NLRB v. Local 357, Int'l Bhd. of Teamsters, ${ }^{42}$ viewing that case as holding that the employer action and union request must be arbitrary or unjustified by a valid reason..$^{43}$

Two members of the Second Circuit panel voted to deny enforcement of the Board's order in Miranda. Judge Medina formulated the central question as, "Whether any sort of discrimination against an employee, affecting the terms and conditions of his employment, can constitute an unfair labor practice under section 8 , even if wholly unrelated to any union considerations." 44 Judge Lumbard, in a separate opinion, concurred in the denial of enforcement. Both judges concluded that only discrimination based upon union membership or other union connected activities is discrimination violating $8(a)(3)$.

40 Cf. Justice Frankfurter's concurrence in Radio Officers Union v. NLRB, 347 U.S. 17, 55 (1954): "[A]ny inference that may be drawn from the employer's alleged discriminatory acts is just one element of evidence which may or may not be sufficient, without more, to show a violation. But that should not obscure the fact that this inference may be bolstered or rebutted by other evidence which may be adduced, and which the Board must take into consideration. The Board's task is to weigh everything before it, including those inferences which, with its specialized experience, it believes can fairly be drawn. . . . Since the issue which the Board thus has to decide involves pre-eminently an exercise of judgment on matters peculiarly within its special competence, little room will be left for judicial review." Id. at 56-57.

41 NLRB v. Nevada Consolidated Copper Corp., 316 U.S. 105, 106 (1942). Compare Radio Officers Union v. NLRB, 347 U.S. 17, 55 (1954) (Frankfurter, J. concurring); Universal Camera Corp. v. NLRB, 340 U.S. 474 (1951).

42365 U.S. 667 (1961). See text at notes 50-55, infra.

43140 N.L.R.B. at 187-88: "an 8(a)(3) or $8(\mathrm{~b})(2)$ violation does not necessarily flow from conduct which has the foreseeable result of encouraging union membership, but that given such 'foreseeable result' the finding of a violation may turn upon an evaluation of the disputed conduct 'in terms of legitimate employer or union purposes." "

44326 F.2d at 175. 
In reaching that conclusion Judge Medina relied heavily on the Second Circuit's earlier decision in $N L R B$ v. Local 294, Int'l Bhd. of Teamsters. ${ }^{45}$ Judge Lumbard considered the case conclusive. The complaint in Local 294 had been issued only against the union. It charged that union officials had attempted to influence the employer to refuse to request a particular truck driver who had been receiving preferences in the assignment of extra runs. The employer refused to agree until the union agent who called the men for work refused to call the driver for jobs. It was uncontradicted that the union's agents had sought to exclude the driver because he "was a troublemaker and no good." The Court denied enforcement of the Board's $8(\mathrm{~b})(2)$ unfair labor practice order, holding that: " $a$ union does not violate section $8(b)(2)$ unless the discrimination which the union seeks would constitute a violation of section $8(a)(3)$ if the employer acted without union suggestion or compulsion." 46 The court then concluded that there could not be a violation of $8(a)(3)$ unless the discrimination by the employer is based on union membership or other union connected activities. ${ }^{47}$

The court's attempt to limit the scope of $8(a)(3)$ and $8(b)(2)$ by its conclusion that $8(b)(2)$ is violated only if the conduct alleged would violate section $8(a)(3)$ if the employer acted independently of union persuasion ${ }^{48}$ needs examination. First, the court reached its conclusion by a non sequitur. That the NLRB has refused to find an unfair labor practice in some cases $^{49}$ of employer differential treatment requested by a union, as the court observed, does not mean that a violation is impossible in any

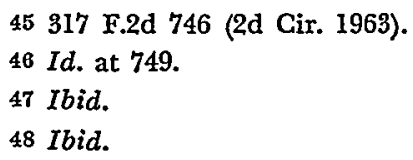

49 The cases the Second Circuit cited, 317 F.2d at 748-49, were: Matter of Yonkers Contracting Co., 135 N.L.R.B. 865 (1962), in which the union prevailed on the employer to hire an employee who was a member of a crew about to be laid off instead of an outside applicant. The Board held that it was clear that the union's function was to attempt to obtain benefits for the employees it represented, and that here it was performing that function in inducing the employer to fill desirable new jobs from within the working force rather than by hiring from outside; Matter of Wilputte Coke Oven Div., Allied Chem. Corp., 135 N.L.R.B. 323 (1962), in which the union requested that an employer who employed both local and out-of-town men lay off out-of-town men first. The employer would not consent to that, but did agree to lay off in equal proportions. One of the out-of-town men who had been laid off charged that "local men" were in fact synonomous with members of the union, and the union's request had therefore been for unlawful preferential treatment. The Board found no basis for the complaint and dismissed it; Matter of Plaza Builders, 134 N.L.R.B. 751 (1961), in which the union prevailed upon the employer to lay off out-of-town men first on a construction project supported by local funds in an area of high unemployment. The examiner and Board found that the requested treatment was not based on union considerations, but was intended to further valid public policy objectives. 
case in which the employer's action would not violate $8(a)(3)$ if taken independently. The cases the court cited seem to indicate only that the differential treatment requested may be justified by a valid employer or union purpose. Secondly, the court did not treat the possibility that union instigation of the employer action is an important element; and may be the very one upon which an inference of encouragement could be based-so long as the differential treatment accorded by the employer is considered "discrimination." But that merely highlights the difficulty with the court's conclusion that the employer's action should be such as would constitute an $8(a)(3)$ violation if taken independently. That requirement is not an exacting one aside from a more precise definition of what the term "discrimination" encompasses.

In addition to rejecting the Board's encouragement theory in Teamsters Local 294 because it stemmed from an "overly broad" reading of Radio Officers, the Second Circuit said the theory "has been completely rejected" by Teamsters Local 357.50

The court's reliance, in Teamsters Local 294 and in Miranda, on Teamsters Local $357^{51}$ seems misplaced, as Judge Friendly argued. In Local 357 the employer discharged a union member at the request of the union in order to comply with a hiring hall contract. The contract provided for referral based on seniority, but on a non-discriminatory basis with respect to union membership. The discharged employee had not been hired through the hall as the contract required. Because the hiring hall contract did not comply on its face with the Board's "Mountain Pacific standards," 52 the Board found a per se violation of $8(\mathrm{~b})(2)$.

The Supreme Court held that discrimination could not be inferred from a contract which on its face provided that employees were to be treated without discrimination. The Court conceded that the existence of the hiring hall might encourage union membership ${ }^{53}$ but observed that

50 317 F.2d at 750 .

51 Local 357, Int'l Bhd. of Teamsters v. NLRB, 365 U.S. 667 (1961).

52 See Mountain Pacific. Chapter of the Associated General Contractors, Inc., 119 N.L.R.B. 883 (1957). In its opinion in that case the Board said it would find hiring hall agreements to be non-discriminatory on their faces only if the agreements explicitly provided that: "(1) Selection of applicants for referral to jobs shall be on a non-discriminatory basis and shall not be based on, or in any way affected by, union membership, by-laws, rules, regulations, constitutional provisions, or any other aspect or obligation of union membership, policies, or requirements. (2) The employer retains the right to reject any job applicant referred by the union. (3) The parties to the agreement post in places where notices to employees and applicants for employment are customarily posted, all provisions relating to the functioning of the hiring arrangement, including the safeguards that we deem essential to the legality of an exclusive hiring agreement." $I d$. at 897.

53 Writing for the majority, Justice Douglas said, "It may be that the very existence of the hiring hall encourages union membership. We may assume that it does. The 
Congress had explicitly indicated that hiring halls were useful and that hiring hall contracts serve legitimate business purposes. ${ }^{54}$ Since the employer had done nothing except comply with the contract, his action was not "the kind of discrimination to which the act was addressed." 55 The case rejected a finding of discrimination predicated on a non-discriminatory hiring hall which served a legitimate purpose. Contrary to the conclusion of the Second Circuit, the case did not indicate that discrimination was prohibited only if it was based upon union membership or activity.

In short, the foregoing discussion illustrates that, apart from discrimination, the requisite elements of $8(a)(3)$ or $8(b)(2)$ violations may be inferred by the Board from any arbitrary conduct. Hence, the scope of Board power depends on the content given the term "discrimination."

The issues involved may be illuminated by considering the three possible meanings of the term, advanced earlier, in the light of their consequences and the purposes and history of the statute. Certainly the "neutral" definition of any differential treatment or distinction is too broad. It would encompass any differences in treatment in the employment relation. The employer would be unable to take reasonable action necessary to conduct his business. The Board and the courts have implicitly avoided such a definition by tolerating, as a reasonable exercise of business judgment, some differential treatment, even when alleged to be based on union considerations. ${ }^{50}$

The second meaning of discrimination-invidious distinction or differentiation based on union relationships-is supported by the weight of

very existence of the union has the same influence. When a union engages in collective bargaining and obtains increased wages and improved working conditions, its prestige doubtless rises and, one may assume, more workers are drawn to it. When a union negotiates collective bargaining agreements that include arbitration clauses and supervises the functioning of those provisions so as to get equitable adjustments of grievances, union membership may also be encouraged. The truth is that the union is a service agency that probably encourages membership whenever it does its job well. But, as we said in Radio Officers v. Labor Board, ... the only encouragement or discouragement of union membership banned by the Act is that which is 'accomplished by discrimination." " 365 U.S. at 675-76.

54 The Court said, "Congress has not outlawed the hiring hall .... Senator Taft made clear his views that hiring halls are useful, that they are not illegal per se, that unions should be able to operate them so long as they are not used to create a closed shop: 'In order to make clear the real intention of Congress, it should be clearly stated that the hiring hall is not necessarily illegal. The employer should be able to make a contract with the union as an employment agency. The union frequently is the best employment agency. The employer should be able to give notice of vacancies, and in the normal course of events to accept men sent to him by the hiring hall. . . " 365 U.S. at 673-74.

$55 I d$. at 675 .

56 See note 83, infra and cases supra note 49. 
authority in the cases ${ }^{57}$ and, the legislative history indicates, is clearly what was meant by the term in the statute.

The legislative history of the precursor of section $8(a)(3)$, section $8(3)$ of the Wagner Act, indicates that the lawmakers were primarily concerned with employer reprisals against employees because of the employees' union activity or membership. The bill, in its journey through the Congress, went from the more particular to the more general. As originally introduced in 1934, it was made an unfair labor practice for an employer

to engage in any discriminatory practice as to wage or hour differentials, advancement, demotion, hire, tenure of employment, reinstatement, or any other condition of employment, which encourages membership or nonmembership in any labor organization. ...58

After amendment in committee, the bill as reported to the Senate made it an unfair labor practice

for an employer, by discrimination in regard to hire or tenure of employment or any term or condition of employment, or by contract or agreement, to encourage or discourage membership in any labor organization . . ...59

The Senate Report on the original bill explained that an employer did not have to hire an incompetent and was free to discharge an employee who lacked skill or ability, but

the employer ought not to be free to discharge an employee merely because he joins an organization or to refuse to hire him merely because of his membership in an organization. Nor should an employer be free to pay a man a higher or lower wage solely because of his membership or nonmembership in a labor organization. 60

The bill failed to pass either house. When reintroduced in 1935, the relevant portions had been altered to their present reading. ${ }^{61}$ Reports in both houses explained that section $8(3)$ rounded out the provisions of section 7(a) of the National Industrial Recovery Act ${ }^{62}$ which prohibited

57 See text accompanying notes 77-9 infra.

581 LEGIS. Hisr. 1985 at 3.

$59 I d$, at 1087 .

$60 \mathrm{Id}$. at 1105 .

61 Id. at 1299-1300; 2 LEGIS. Hist. 1935 at 2449.

6248 Stat. 195 (1933) Section 7(a): "Every code of fair competition, agreement, and license approved, prescribed, or issued under this title shall contain the following conditions: (1) That employees shall have the right to organize and bargain collectively 
yellow dog contracts and interference, restraint, or coercion of employees in their organizational rights. ${ }^{63}$

There was little debate on the section. Senator Wagner, in introducing the bill and discussing it on the floor, seemed implicitly to be referring to discrimination against an employee because he was a union member. ${ }^{64}$ Senator Walsh emphasized that an employer retained the power to make necessary employment decisions, but that he could not dismiss employees "when they are objectionable on no other ground than that they belong to or have organized a labor union." 65

Thus, the legislative history of the 1935 Act indicates an intention to prevent employer reprisals or ill treatment of employees because of membership or participation in union activities. While "discrimination" is not defined, the legislators had in mind conduct such as discharges, refusals to hire or to promote, or the payment of lower wages because of the employee's union activity.

The history of the Taft-Hartley amendments, and of section $8(\mathrm{~b})(2)$ in particular, throws additional light on what the legislators conceived to be "discrimination." In 1947, Congress was concerned about pressure by unions on employers to discharge or refuse to hire employees under union security arrangements when those employees had been refused admission to or had been ousted from the union. The Senate committee report on the bill stated that section $8(b)(2)^{66}$ was "designed to protect individual employees from discrimination in employment induced by a labor organization which has a union-shop contract with an employer ...."67

through representatives of their own choosing, and shall be free from interference, restraint, or coercion of employers of labor, or their agents, in the designation of such representatives or in self-organization or in other concerted activities for the purpose of collective bargaining or other mutual aid or protection; (2) that no employee and no one seeking employment shall be required as a condition of employment to join any company union or to refrain from joining, organizing, or assisting a labor organization of his own choosing, ..." I LEGIS. HIST. 1935 at 198-99.

632 LEgis. HIST. 1935 at 2310, 2927, 2973, 3068.

64 Id. at 2335.

$65 \mathrm{Id}$. at 2370.

66 The section, in S. 1126 as reported, provided: "It shall be an unfair labor practice for a labor organization or its agents-... (2) to persuade or attempt to persuade an employer to discriminate against an employee with respect to whom membership in such organization has been denied or terminated on some ground other than his failure to tender the dues and initiation fee uniformly required as a condition of acquiring or retaining membership or because he engaged in activity designed to secure a determination pursuant to section $9(\mathrm{c})(\mathrm{I})(\mathrm{A})$ at a time when a question concerning representation may appropriately be raised." I N.L.R.B. LEGISLATIVE HISTORY of THE LABOR MANagement RELAtions Act, 1947112 (1948) [hereinafter cited as Legis. Hisr. 1947].

67 Id. at 427. 
According to the report, unions were free to observe whatever membership provisions they desired but only two reasons were specified for "effecting the discharge of, or other job discrimination against, an employee." 68

Discrimination is permitted only if [the employee] has failed to tender dues and initiation fees or has engaged in 'dual union' activity or activity designed to oust the incumbent union as exclusive representative, at an inappropriate time. ${ }^{69}$

The language "discrimination is permitted" implies that discrimination is discharge or other prejudicial treatment of an employee because of the quality or absence of his union membership.

As they passed each house and went to conference, the bills differed somewhat from each other ${ }^{70}$ and, significantly, from the final product. The reasons for the ultimate changes in conference are not revealed. The House Conference Report stated that the Senate amendments providing for union unfair labor practices had been broader in scope than the corresponding provisions of the House bill, and then explained the conference agreement in the following significant language:

(1) Section $8(b)(2)$ is expanded so as to prohibit all attempts by a labor organization ... to cause an employer to discriminate against an employee in violation of section $8(a)(3)$. The latter section, as heretofore explained, prohibits an employer from discriminating against an employee by reason of his membership or nonmembership in a labor organization, except to the extent that he obligates himself to do so under the terms of a permitted union shop or maintenance of membership contract. ${ }^{71}$

68 Ibid.

c0 Ibid. (Emphasis added.) The minority report objected strongly to sections 8(a)(3) and $8(\mathrm{~b})(2)$ and stated, "If these provisions are merely designed to outlaw the closedshop closed-union arrangement and to permit union security agreements not based on the closed union practice, they have gone far beyond what is needed to achieve that purpose." Id. at 472. The clear implication is that the legislative purpose, at least as seen through the eyes of the minority, was to deal with abuses of union security arrangements.

70 H.R. 3020, as it passed the House, provided in section $8(c)(7)$ that it was an unfair labor practice for a labor organization "to take any action or make any arrangements that would have the effect of requiring an employer to deny employment to, or terminate the employment of, any individual (A) to whom membership in such organization was not available on the same terms and conditions as those applicable to other members, or (B) to whom membership in such organization was denied on some ground other than failure to tender the initiation fees and dues uniformly required as a condition of acquiring or retaining membership." I LEGIS. HIST. 1947 at 181-82. H.R. 3020, as it passed the Senate, had been amended by Senate substitute, and read as in note 66 , supra. $I d$. at 240.

71 Id. at 548. (Emphasis added.) 
The excerpt is significant for it reflects preoccupation with discrimination based on membership or nonmembership in a labor organization. This is confirmed by language in the debates before passage of the bills. Senator Taft, among others, spoke of an employer being caused to exclude a man from work because he had been fired from the union.72 Taft's use of "discrimination" as found in $8(a)(3)$ clearly referred to discharge for nonmembership. ${ }^{73}$

In short, the history of the 1947 Act indicates a concern primarily with union coercion to get an employer to discharge or accord less favorable treatment to employees because of the loss of or failure to obtain membership.

There is no indication that "discrimination" was thought to include racial discrimination. Allusions to discrimination on racial grounds were almost nonexistent. Senator Murray, a vigorous opponent of the TaftHartley bills, did refer to 8(a)(3) as extending federal controls over employer and union discrimination based on race; ${ }^{74}$ and Representative Smith of Virginia, a proponent of the bill, defended himself against the charge in an "anonymous circular" that the bill "would put into effect the so called FEPC bill" by denying that it compelled employers or unions to change any of their practices regarding racial distinctions in hiring or membership. ${ }^{75}$ The fact that the same Congress that passed the Taft-Hartley Act refused to pass several "FEPC" bills which sought to prohibit discrimination in employment on racial and other grounds ${ }^{76}$ lends some support to this view.

Although the cases have not carefully articulated the content of the term, they generally reinforce the implication of the legislative history

722 Legrs. Hist. 1947 at 1010, 1012, 1420, 1497, 1508. See also remarks of Sen. Ellender, id. at 1068; and discussion of Sens. Taft, Pepper, and others, id. at 1094-98.

73 See $i d$. at 1010. In a somewhat enigmatic statement referring to now section 8(b)(2) Rep. Hartley had referred to the bill as conferring a "bill of rights" upon the worker including the right "to require the union that is his bargaining agent to represent him without discriminating against him in any way or for any reason, even if he is not a member of the union." 1 Legis. Hist. 1947 at 616.

742 LEGIS. HIST. 1947 at 1569: "But this provision takes an enormous forward step in the direction of regulating the employment practices of industry and the exclusion practices of unions, without any adequate study having been given the matter. It is unhappily true that in certain sections of our country, race prejudices are strong and deep. With time and education they will, I am sure, disappear; and there are encouraging signs looking in that direction. But despite my conviction that the sooner we can eliminate race and religious prejudices the better, I hesitate to approve so vital a step at this time as making the Federal Government the overseer of employer and union practices in all the states."

751 LEGIS. HIST. 1947 at 906.

7693 CoNG. REc. 46, 47, 262, 329, 2688, 2788, 2932, 2999, 3375, 3674, 4343, 4552, 10100 (1947). 
that discrimination means invidious differential treatment based on or motivated by union relationships. The relevant early Supreme Court cases sustained Board findings of violations involving apparent employer reprisals against employees because of their union activities or affiliation. Included were cases in which the employer discharged workers who became union members or were active in union affairs, ${ }^{77}$ refused initial hiring of men involved in union activities, ${ }^{78}$ or refused to rehire certain of the most active union members when employees offered to return to work following a strike. ${ }^{79}$ In each case the treatment was found by the Board to be the consequence of union activity by the victim employee. From these cases, implicitly involving violations of discouragement, one must conclude that "discrimination" refers to differential treatment based on union relationships. ${ }^{80}$

"Discrimination" may reasonably be argued to have the third meaning set forth above-differentiation or distinction taken without sufficient reason. Support for giving section $8(a)(3)$ this meaning may be found by analogy to other cases involving allegations of discriminatory treatment in violation of the national labor policy, particularly allegations of violation by a union of its duty of fair representation. Under its duty of fair representation, the union undertakes what may be described as a fiduciary responsibility to represent the interests of the members of the bargaining unit fairly. This duty does not prevent all differences in treatment; but in each case whether the different treatment violates the union's duty to minorities in the unit and to its members depends upon the nature of the interest harmed and the justification for such harm. ${ }^{81}$ Differential treatment based on race would always be vulnerable, ${ }^{82}$ except perhaps for a beneficial inequality. In some circumstances a legitimate

77 NLRB v. Waterman S.S. Co., 309 U.S. 206 (1940); Associated Press v. NLRB, 301 U.S. 103 (1937); NLRB v. Jones \& Laughlin Steel Corp., 301 U.S. 1 (1937). See also Republic Aviation Corp. v. NLRB, 324 U.S. 793 (1945).

78 Phelps Dodge Corp. v. NLRB, 313 U.S. 177 (1941).

79 NLRB v. Mackay Radio \& Telegraph Co., 304 U.S. 333 (1938).

80 See International Assoc. of Machinists, Lodge No. 35 v. NLRB, 311 U.S. 72, 81 (1940) where the Court explicitly refers to "discrimination upon the basis of union membership" constituting a violation of $8(3)$.

81 See Note, Duty of Union to Minority Groups in the Bargaining Unit, 65 HARv. L. REv. 490 (1952). Regarding the duty of fair representation, see generally Cox, The Duty of Fair Reperesentation, 2 VILL. L. REV. 151 (1957); Sovern, The National Labor Relations Act and Racial Discrimination, 62 CoLUM. L. REv. 563 (1962). In regard to the union's duty to minority groups in bargaining and in grievance prosecution, see generally Wellington, Union Democracy and Fair Representation: Federal Responsibility in a Federal System, 67 Yale L.J. 1327 (1958); Note, 65 HARv. L. REv. 490 (1952).

82 Cf. Brotherhood of R.R. Trainmen v. Howard, 343 U.S. 768 (1952); Tunstall v. Brotherhood of Locomotive Firemen, 323 U.S. 210 (1944); Steele v. Louiseville \& N. R.R., 328 U.S. 192 (1944). 
business or union purpose, or a purpose which vindicates an important public policy objective, will justify differential treatment. ${ }^{83}$

The concept of "discrimination" as any differential treatment taken without sufficient justification appears, at first, to be the most reasonable, for it allows a weighing of interests, balancing the impact on employees' organizational rights of different treatment-even if based partly on union considerations-against the business purpose or other policy objective of the employer in his action. ${ }^{84}$ Such a balancing seems implicitly to have been decisive in the Mackay case in which the employer's legitimate business purpose of continuing operations during an economic strike was found to warrant hiring replacements. ${ }^{85}$ Even some racial distinctions might be justified. It might be proper for an employer to add Negro workers who are not union members to his work force, although white union members are available to work, ${ }^{86}$ in order to promote the public policy of increasing employment opportunities for Negroes.

83 Thus a union may demand-and presumably an employer may sign-a contract giving top seniority to employees who are union officials because stability, continuity, and responsibility in bargaining benefit the business operations and neither be in violation of the union's duty of fair representation nor cause the employer to be guilty of "discrimination." Aeronautical Industrial District Lodge 727 v. Campbell, 337 U.S. 521 (1949), (suit for back pay by employee who was laid off temporarily, although union chairmen who had less time with the company were retained). Justice Frankfurter commented upon the key role of union chairmen in collective bargaining and the importance of their continuity in office and said, "A provision for the retention of union chairmen beyond the routine requirements of seniority is not at all uncommon and surely ought not to be deemed arbitrary or discriminatory." Id. at 528. The Court clearly implied that it is not discriminatory for the employer to agree to such a seniority provision. See also Pacific Gamble Robinson Co. v. NLRB, 186 F.2d 106 (6th Cir. 1960), a $\$ \$ 8(a)(1)$ and (5) case, in which the employer's offer of slightly higher wage rates to workers replacing strikers was found to be justified by his right to try to keep his business going. Compare Radio Officers Union v. NLRB, 347 U.S. 17 (1954), in which the Gaynor News Company's contention that its business judgment justified it giving higher raises to union members than to non-union members was held not to be a legitimate justification. Cf. Ford Motor Co. v. Huffman, 345 U.S. 330 (1953) (suit to invalidate seniority clause in collective bargaining agreement), which indicates the employer and the union may sign an agreement giving a veterans seniority credit to new employees for active duty time served before employment in excess of the requirements of the Selective Service Act, and not be guilty of discrimination because their action is in harmony with the purposes of that Act.

84 Compare NLRB v. Erie Resistor Corp., 373 U.S. 221, 228-29 (1963).

85 NLRB v. Mackay Radio \& Telegraph Co., 304 U.S. 333 (1938). The Board entered unfair labor practice orders under both sections $8(a)(1)$ and $8(a)(3)$. The Court held that it was not an unfair labor practice "to replace the striking employees with others in an effort to carry on the business." Id. at 345. The Court discussed the way the employer might have refused reinstatement on valid grounds and thus avoid having his differential treatment termed "discrimination." Id. at 346-47. The Court in Mackay affirmed the Board's order finding that the employer's refusal to rehire five strikers who had been very active in union affairs was a violation of section 8(a)(3). Id. at 347.

$86 \mathrm{Cf}$. the difficulty between Plumbers Local Union 2 and Astrove Plumbing \& Heating Corp., involving the New York City Public Works Department and the City 
This concept of discrimination seems to allow the most flexible implementation of the labor statute to each case without the mechanical expansiveness of the first meaning of discrimination-any differentiation or distinction-or the narrowness of the second-any differentiation based on union relationships. Arbitrary or invidious distinctions would be proscribed, and those distinctions by an employer which are justified by a valid business 87 or other purpose as well as those requests by a union which do not violate its duties to the members of the bargaining unit would be tolerated. The determination that the differential treatment involved in a particular case is arbitrary or invidious and therefore "discrimination" violating the statute would be made by the Board, weighing all the factors involved in the case.

Although such a balancing of interests seems reasonable, the legislative history indicates the less expansive concept of discrimination-those invidious distinctions made because of union relationships-was intended. Other bases for invidious distinctions, even racial ones, were not intended or thought to be encompassed by the act. ${ }^{88}$ Additional considerations, equally applicable to sections $8(b)(1)(A)$ and $8(b)(3)$, militate against creating a broad NLRB administrative remedy. An already

Commission on Human Rights, in late April and May, 1964. See N.Y. Times, May 2, 1964, p. 1, col. 3 (city ed.).

87 An employer charged with a violation of section $8(a)(3)$, on the basis of his acquiescence to a union request, may seek to justify his conduct on the grounds that it was motivated by a desire to preserve industrial peace and thus that it was justified by a legitimate business purpose. Mr. Justice Harlan, concurring in Teamsters Local 357,365 U.S. 667,677 (1961), addressed himself to this contention and concluded that, "The employer's non-discriminatory reason for encouraging union membership-to avoid the economic pressure the union could impose upon him-was surely no longer intended to be a justification for such employer action after the passage of $\S 8(\mathrm{~b})(2)$, a statutory provision the very working of which presupposes that union coercion can cause a violation of $\S 8(\mathrm{a})(3) . "$ Id. at 683 .

88 See text accompanying notes 74-76 supra. It should be noted, however, that the oft-cited language in the debates over the Taft-Hartley Act to the effect that unions could continue to discriminate in membership so long as the lack of membership was not used as a reason for preventing hiring by the employer, see, e.g., Sen. Rep. No. 105 on S. 1126, I LEGIs. HIST. 1947 at 427; remarks of Sen. Taft, 2 LEgrs. HIST. 1947 at 1010, may rely on a distinction which is non-existent in industries which have a closed shop tradition or a tradition of refusal to work with non-union members, or in industries allowing unions to run hiring halls the services of which non-union members in practice fear to use, see Local 357, Int'l Bhd. of Teamsters v. NLRB, 365 U.S. 667, 685-94 (1961) (Clark, J. dissenting). In these industries, such as the building trades, racial discrimination in apprenticeship programs and in membership has the practical result of exclusion from employment. For one solution to the problem of racial discrimination in apprenticeship programs in the building trades, see Todd v. Joint Apprenticeship Comm., 55 L.R.R.M. 2171 (N.D. Ill. 1963) which found a constitutional basis to order the end of racial discrimination in the amount of federal and local government support of the apprentice school. But see Gaynor v. Rockefeller, 56 L.R.R.M. 2210 (N.Y. App. Div. 1964). 
heavily burdened Labor Board may be swamped by complaints of abuse and ill-treatment by employees. Not only may there be numerous cases which, like Miranda, do not involve racial discrimination but allege other kinds of injustice and ill-treatment at the hands of the union or employer, but even more burdensome may be the number of cases which allege differential treatment on racial grounds. Concededly, the possibility of many meritorious claims of injustices, particularly because of race, suggests the need to prevent such abuses. But it does not mean the unfair labor practice machinery is historically or practically the appropriate mechanism.

Furthermore, charging the Board with weighing' all the interests involved gives the Board responsibility over some matters not within its special competence. The weighing of contrary public policies, ${ }^{89}$ particularly those outside the policy which fostered the NLRB, is not a matter of Board expertise. That function is for the courts.

A serious question of possible preemption of state remedies is also raised by the Board's extension of its jurisdiction to complaints of discrimination on other than union grounds. Any allegation of discriminatory or unjust treatment may be arguably an unfair labor practice. Federal and state courts are preempted from hearing such cases because the Board has primary jurisdiction over them. ${ }^{90}$ In racial cases, state fair employment practices laws and administrative remedies created under such state commissions may also be preempted. The language of the state statutes directly covers the type of conduct which might be alleged as $8(a)(3)$ or $8(b)(2)$ violations. ${ }^{91}$ Conflict in remedies or in interpretation

89 As in the selective service case discussed supra. See text accompanying note 83 supra.

90 San Diego Bldg. Trades Council v. Garmon, 359 U.S. 236 (1959). "When an activity is arguably subject to $\S 7$ or $\S 8$ of the Act, the States as well as the federal courts must defer to the exclusive competence of the National Labor Relations Board if the danger of state interference with national policy is to be averted." $I d$. at 245. But cf., Colorado Anti-Discrimination Comm. v. Continental Air Lines, Inc., 372 U.S. 714 (1963), holding that Colorado is not prevented from applying its Anti-Discrimination Act to an interstate air carrier by the Federal Aviation Act of 1958 or the Railway Labor Act. See generally State-Federal Clash Possible over FEP-Union Contracts, 56 LAB. REL. REP. 394 (1964).

91 See, e.g., N.Y. ExEc. LAW 296 which provides:

1. It shall be an unlawful discriminatory practice:

(a) For an employer, because of the age, race, creed, color or national origin of any individual, to refuse to hire or employ or to bar or to discharge from employment such individual or to discriminate against such individual in compensation or in terms, conditions or privileges of employment.

(b) For a labor organization, because of the age, race, creed, color or national origin of any individual, to exclude or to expel from its membership such individual or to discriminate in any way against 
of national labor policy or other public policies is possible. And this possibility has been a sufficient rationale for preemption of state jurisdiction over matters subject to NLRB administrative remedies. ${ }^{92}$ It would be anomalous in this instance to select a definition resulting in preemption, since it would mean giving the Board power to consider policy matters beyond its expertise while denying that power to agencies specifically entrusted with making such determinations.

With regard to racial discrimination, it is also interesting to note that approval of the use of the unfair labor practice machinery for charges of racial discrimination would give much of what was withheld, with regard to enforcement, in the journey through the legislative process ${ }^{93}$ of Title VII (the Equal Employment Opportunity Law) of the Civil Rights Act of 1964.94 The language of section 703(a) and (c), ${ }^{95}$ creating employer and union "unlawful employment practices," corresponds closely to state fair employment practices statutes ${ }^{26}$ and explicitly covers the type of discrimination sought to be included in $8(a)(3)$ and $8(b)(2)$.

The furnishing of public counsel to prosecute complaints is a great advantage of the NLRB remedy. In the Civil Rights bill as it passed the House of Representatives, an individual could file a charge of an unlawful employment practice and, after investigation and effort by the Commission to gain voluntary compliance, could also have the Commission file a civil action for enforcement of the act. However, before Senate

any of its members or against any employer or any individual employed by an employer.

CAL. LABOR CODE $\S 1420$ specifies unlawful employment practices in virtually identical wording.

92 See San Diego Bldg. Trades Council v. Garmon, 359 U.S. 236 (1959). But cf. Colorado Anti-Discrimination Comm. v. Continental Air Lines, Inc., supra note 90. See generally Meltzer, The Supreme Court, Congress, and State Jurisdiction over Labor Relations, 59 Colum. L. REv. 6, 269 (1959).

03 For a summary of the legislative action, see 56 LAB. REL. REP. 281 (1964).

9478 Stat. 241 (1964).

95 Section 703(a), 78 Stat. 255 (1964), of the Civil Rights Act provides:

It shall be an unlawful employment practice for an employer-

(1) to fail or refuse to hire or to discharge any individual, or otherwise to discriminate against any individual with respect to his compensation, terms, conditions, or privileges of employment, because of such individual's race, color, religion, sex, or national origin; or

(2) to limit, segregate, or classify his employees in any way which would deprive or tend to deprive any individual of employment opportunities or otherwise adversely affect his status as an employee, because of such individual's race, color, religion, sex, or national origin.

Section 703(c), 78 Stat. 255 (1964), says:

It shall be an unlawful employment practice for a labor organization . . .

(3) to cause or attempt to cause an employer to discriminate against an individual in violation of this section.

86 See note 91 , supra. 
acceptance, the so-called "Dirksen amendments" altered the bill to provide that if the Equal Employment Opportunities Commission (EEOC) fails to secure compliance within a specified time the aggrieved individual is notified and must himself file a civil action within thirty days. ${ }^{97}$ Although the court may appoint an attorney and authorize the initiation of the action without payment of costs, fees or security-or may permit the Attorney General to intervene if he certifies that the case is of public importance-it is evident that the administrative remedy under the Labor Act, with the NLRB General Counsel prosecuting the action if court enforcement is necessary, is easier for the grievant. This is one reason the General Counsel for the National Association for the Advancement of Colored People hailed the Labor Board's decision in the Independent Metal Workers case, despite the signing into law the same day of the Civil Rights Act.98

The expression of national policy in the Civil Rights Act raises some questions about the unfair labor practice remedy in racial cases. It may be that the Senate amendment strongly implies that an administrative agency was not to have power to initiate suits for enforcement in racial cases. On the other hand, the amendment-part of an omnibus package of amendments thought to be necessary for passage of the total billneed not have any specific significance; or may indicate merely that the Senate did not want to give such powers to that particular agency, one which was new and untried and-as a "federal FEPC"-historically controversial. But the question asked by the dissenters in Independent Metal Workers is still relevant: "If a separate agency is created to handle the task of eliminating employment discrimination by unions and employers based on race, should the Board have a duty in this field?"99

It may also be significant that the EEOC is given authority to relinquish part or all of its enforcement function by entering into a cooperative agreement with a state or local agency when an unlawful employment

97 Another significant enforcement provision of the act is that in $\$ 707$ which authorizes the Attorney General to file an action requesting injunctions or other relief when he "has reasonable cause to believe that any person or group of persons is engaged in a pattern or practice of resistance to the full enjoyment of any of the rights secured by this title, and that the pattern or practice is of such nature and is intended to deny the full exercise to the rights herein described ...."

98 Another factor is that the Civil Rights Act is phased into effect over a period of years, according to the size of the businesses affected. See $\S 701$ (b). Robert L. Carter, a general counsel of the NAACP, hailed the Independent Metal.Workers decision by the Board as a breakthrough of "almost revolutionary proportions" so far as labor law is concerned. He added that he would prefer to process complaints through the NLRB rather than through the fair employment practices provisions of the Civil Rights Act since the NLRB procedures would be easier, less costly to the individual, and more widely applicable. N.Y. Times, July 3, 1964, p. 1, col. 6 .

99147 N.L.R.B. No. 166, at 21 (1964). 
practice occurs in a state or city which has its own fair employment practices law. ${ }^{100}$ Even if there is no such cooperative agreement, the state and local authorities are given time to deal with the situation first.101 These provisions for cooperation with and deference to state FEPCs indicate an expression of policy sharply contrasting with the preemption of such state agencies which is possible if the NLRB's unfair labor practice machinery is involved.

\section{ConCLusion}

"Discrimination," as the term is used in section $8(a)(3)$ and by reference in $8(b)(2)$ should be limited to that differential treatment which is based on or related to "union membership, loyalty, the acknowledgement of union authority or the performance of union obligations"102 by the employee involved. Since the maximum obligation of "membership" the union can impose under the act-by union security agreement with the employer-is the payment of dues and a reasonable initiation fee, ${ }^{103}$ the attempt to enforce other obligations or deference to the union by getting the employer to afford differential treatment to any employee is forbidden. ${ }^{104}$ As before, the term should be conceived of as modified by "arbitrary" or "invidious." Thus a business purpose or union objective valid under the national labor policy may justify even differential treatment based on union relationships. ${ }^{105}$ Such a definition of discrimination best accords with the Congressional intent. Such a limited definition also will prevent an undue expansion of Labor Board jurisdiction; an expansion undesirable because the burden may divert the Board's attention from matters indisputably committed to its care to questions beyond its special area of competence. A limited definition also will prevent preemption of tribunals whose function is to consider charges of racial discrimination. Elimination of racial discrimination and other arbitrary treatment is a worthy objective, but expansion of the unfair labor practices of sections $8(a)(3)$ and $8(b)(2)$ is an inappropriate method.

100 Civil Rights Act $\S 709(\mathrm{~b})$.

101 Civil Rights Act $\S 706(b)$ (c).

102 Miranda Fuel Co., 140 N.L.R.B. 181, 187 (1962) (McCulloch and Fanning, dissenting); Independent Metal Workers Union, Local 1 \& 2, 147 N.L.R.B. No. 166 at 21 (McCulloch and Fanning, dissenting).

103 NLRB v. General Motors Corp., 373 U.S. 734, 742 (1963).

104 See e.g., Radio Officers Union v. NLRB, 347 U.S. 17 (1954).

105 See note 83, supra. 